\title{
TATA KELOLA DAN KINERJA KEUANGAN PADA KANTOR KECAMATAN WANEA KOTA MANADO
}

\author{
Nivi Chintia Walangitan ${ }^{1}$, Jenny Morasa ${ }^{2}$, Lidia M. Mawikere ${ }^{3}$ \\ 1,2,3 Jurusan Akuntansi, Fakultas Ekonomi dan Bisnis, Universitas Sam Ratulangi, Jl. Kampus UNSRAT, \\ Manado, 95115, Indonesia \\ E-mail: chintiawalangitan@gmail.com
}

\begin{abstract}
Whether or not a government institution runs well or poorly provided services depends on the leadership policy in its management. The purpose of this study was to determine public governance and financial performance at the Wanea District Office. The analytical method used is qualitative analysis with Primary data. The results showed that (1) the implementation of transparency in the Wanea District Office was good. (2) The implementation of accountability in the form of the ability to present government information openly, (3) quickly and accurately to the public,(4) the ability to provide satisfactory services to the public, the ability to provide space for the community, the ability to explain and account for any public policy proportionally and (5) the provision of facilities for the public to assess government performance. So the implementation of the principle of accountability in Wanea District is good. Financial performance in the Wanea District Office is good. Keywords: transparency; accountability; government financial performance
\end{abstract}

\section{PENDAHULUAN}

Proses penyelenggaraan kekuasaan negara dalam melaksanakan penyediaan public goods and services merupakan bagian dari good governance. Terselenggaranya suatu pemerintah daerah yang baik sebagai upaya good governance ditunjukkan dengan transparansi, partisipasi, dan akuntabilitas suatu instansi pemerintah yang merupakan suatu perwujudan kewajiban untuk mempertanggungjawabkan keberhasilan atau kegagalan pelaksanaan masalah instansi yang bersangkutan. Dalam upaya peningkatan kinerja kepemerintahan yang baik, maka Pemerintah Kota Manado khususnya Kecamatan Wanea secara terus menerus melakukan perbaikan dalam penyajian pelaporan keuangan yang meliputi segala aspek baik yang berkaitan dengan penyediaan dan penyampaian informasi keuangan maupun mekanisme penyampaian informasi keuangan itu sendiri. Banyak pihak yang mengandalkan informasi keuangan yang dipublikasikan oleh pemerintah daerah sebagai dasar pengambilan keputusan. Jika nilai informasi laporan keuangan buruk, artinya laporan tersebut dihasilkan dari sistem akuntansi yang buruk sehingga didalamnya mengandung kesalahan, tidak disusun sesuai standar pelaporan dan tidak andal dalam penyampaiannya maka hal ini akan berdampak buruk bagi para pengguna laporan dan penyajian laporan itu sendiri (Sujarweni, 2015:11).

Seiring dengan semakin meningkatnya Anggaran Pendapatan dan Belanja Kabupaten/Kota dari tahun ke tahun, maka dari sisi akuntansi hal tersebut menunjukkan bahwa jumlah transaksi keuangan pemerintah juga menunjukkan kuantitas yang semakin besar dan kualitas yang semakin rumit dan kompleks. Peningkatan jumlah transaksi yang semakin besar dan semakin kompleks tentu harus diikuti dengan peningkatan kemampuan pengelolaan keuangan pemerintah. Untuk mewujudkan tata pemerintahan yang baik membutuhkan waktu yang tidak singkat dan juga upaya yang terus menerus. Disamping itu, perlu juga dibangun kesepakatan serta rasa optimis yang tinggi dari seluruh komponen bangsa yang melibatkan tiga pilar berbangsa dan bernegara, yaitu para aparatur negara, pihak 
swasta dan masyarakat untuk menumbuhkembangkan rasa kebersamaan dalam rangka mencapai tata pemerintahan yang baik dan terutama adanya sikap jujur pada rakyat adalah titik tolak untuk menciptakan pemerintahan yang tidak hanya kuat (strong government), melainkan juga pemerintahan yang bersih dan berwibawa (good governance).

Kantor Camat merupakan tempat berlangsungnya proses pelayanan yang dibutuhkan oleh masyarakat. Didalamnya terdapat beberapa komponen yang saling melengkapi seperti, pimpinan (Camat), pegawai, serta sarana dan prasarana sebagai alat operasional kerja. Berjalan atau tidaknya sebuah lembaga pemerintah baik buruknya pelayanan yang diberikan tergantung kepada kebijakan pimpinan dalam pengelolaannya, maka untuk menciptakan suasana hidup dalam sebuah lembaga, Pimpinan harus berperan aktif dalam kegiatan pengelolaan maupun pengawasannya. Kecamatan Wanea sebagai salah satu bagian dari wilayah Pemerintahan Kota Manado. juga perlu meningkatkan dan menerapkan tata kelola pemerintahan yang baik atau good governance guna mewujudkan sistem pemerintahan yang bersih dan pro rakyat untuk menunjang otonomi daerah terlaksana dengan baik.

\section{TINJAUAN PUSTAKA}

Mardiasmo (2016:1) menyatakan bahwa dalam waktu yang relatif singkat akuntansi publik telah mengalami perkembangan yang pesat. Saat ini telah terdapat perhatian yang lebih besar terhadap praktek akuntansi yang dilakukan oleh lembaga-lembaga pemerintah, perusahaan milik negara/daerah, dan berbagai organisasi publik lainnya di bandingkan dengan pada masa-masa sebelumnya. Terhadap tuntutan yang lebih besar dari masyarakat untuk dilakukan transparansi dari akuntabilitas publik oleh lembaga-lembaga publik.

Menurut Mursyidi (2013:1), akuntansi pemerintahan (governmental accounting) banyak menyatakan teminologi lama dan bergeser ke istilah akuntansi sektor publik. Akuntansi pemerintahan adalah mekanisme akuntansi yang memproses transaksi keuangan yang berkaitan dengan pengelolaan keuangan negara baik tingkat pusat maupun tingkat daerah. Nordiawan et al. (2009:4) menyatakan bahwa akuntansi pemerintahan mengkhususkan dalam pencatatan dan pelaporan transaksi-transaksi yang terjadi di badan pemerintah. Akuntan pemerintah menyediakan laporan akuntansi tentang aspek kepengurusan dari administrasi keuangan negara. Selain itu, bidang ini meliputi pengendalian atas pengeluaran melalui anggaran negara, termasuk kesesuaiannya dengan Undang-Undang yang berlaku. Penilaian kinerja digunakan untuk menilai kemajuan pekerjaan atas pencapaian tujuan dan sasaran yang ditentukan, termasuk informasi efisiensi penggunaan sumber daya dalam menghasilkan barang dan jasa, kualitas barang dan jasa, perbandingan hasil dan target, dan efektivitas tindakan dalam mencapai tujuan.

Tata kelola pemerintah merupakan proses formulasi dan melaksanakan kebijakan, peraturan serta prioritas-prioritas pembangunan melalui interaksi antara eksekutif, legislatif, dan birokrasi dengan partisipasi dari masyarakat sipil dan masyarakat ekonomi (bisnis). Hakikatnya pemerintah yang baik adalah menganggap bahwa kekuasaan amanat untuk bisa melayani masyarakat dengan maksimal. Halim dan Kusufi (2014:18) mengartikan bahwa good governance dalam proses penyelenggaraan kekuasaan negara merujuk pada arti melaksanakan penyediaan pelayanan public good and service, dimana masyarakat menjadi tujuan untuk menyediakan pelayanan prima. Menurut Mahmudi (2018:26), pelayanan umum adalah kegiatan yang dilakukan oleh seseorang atau sekelompok orang dengan landasan faktor materil melalui sistem, prosedur dan metode tertentu dalam rangka usaha memenuhi kepentingan orang lain sesuai dengan haknya.

Transparansi adalah adanya kebijakan terbuka bagi pengawasan sedangkan yang dimaksud dengan informasi adalah informasi mengenai setiap aspek kebijakan pemerintah yang dapat dijangkau publik. Keterbukaan informasi diharapkan akan menghasilkan persaingan politik yang sehat, toleran, dan kebijakan dibuat berdasarkan preferensi publik 
(Hasana dan Fauzi, 2017:35). Akuntabilitas berasal dari istilah dalam bahasa Inggris yaitu accountability yang berarti pertanggunganjawaban atau keadaan untuk dipertanggungjawabkan atau keadaan untuk diminta pertanggunganjawaban. Akuntabilitas (accountability) yaitu berfungsinya seluruh komponen penggerak jalannya kegiatan pemerintahan sesuai tugas dan kewenangannya masing-masing.

Akuntabilitas dan transparansi dalam pengelolaan keuangan pemerintah pusat maupun daerah sebagai organisasi sektor publik merupakan tujuan penting dari reformasi akuntansi dan administrasi sektor publik. Untuk dapat memastikan bahwa pengelolaan keuangan pemerintah yang telah dilakukan aparatur pemerintah, maka fungsi akuntabilitas dan audit atas pelaporan keuangan sektor publik harus berjalan dengan baik. Seiring dengan tuntutan masyarakat agar organisasi sektor publik meningkatkan kualitas, profesionalisme dan akuntabilitas publik dalam menjalankan aktivitasnya, diperlukan audit yang tidak hanya terbatas pada keuangan dan kepatuhan saja, tetapi perlu diperluas dengan melakukan audit terhadap kinerja sektor publik. Dengan adanya transparansi dan akuntabilitas dalam laporan keuangan maka akan membuat laporan keuangan yang berkualitas dan terciptanya pemerintahan yang baik.

Menurut Munawir (2016:26), pelayanan umum adalah kegiatan yang dilakukan oleh seseorang atau sekelompok orang dengan landasan faktor materil melalui sistem, prosedur dan metode tertentu dalam rangka usaha memenuhi kepentingan orang lain sesuai dengan haknya. Pengelolaan keuangan daerah tidak dapat dilepaskan dari keberadaan UndangUndang Nomor 17 Tahun 2003 tentang Keuangan Negara, Undang-Undang Nomor 1 Tahun 2004 tentang Perbendaharaan Negara dan Undang-Undang Nomor 15 Tahun 2004 tentang Pemeriksaan Pengelolaan dan Tanggung Jawab Keuangan Negara. Dengan terbitnya UndangUndang Nomor 32 Tahun 2004 dan Undang-Undang Nomor 33 Tahun 2004 maka berbagai prinsip dasar yang ada dalam Undang-Undang Keuangan Negara, pengelolaan dan tanggung jawab keuangan negara kembali dipertegas dan menjadi acuan dalam pengalihan keuangan daerah. Pengelolaan Keuangan Daerah meliputi tiga tahapan yaitu: perencanaan dan penganggaran, pelaksanaan serta pertanggungjawaban (Walangitan, 2014). Mulyadi (2002:16) menjelaskan bahwa penilaian kinerja adalah penentuan secara periodik efektivitas operasional suatu organisasi, bagian organisasi, dan karyawannya berdasarkan sasaran, standar, dan kriteria yang telah ditetapkan sebelumnya.

\section{METODE PENELITIAN}

Jenis data yang digunakan dalam penelitian ini adalah data kualitatif, dimana menurut Kuncoro (2014:56), data kualitatif yaitu data yang diperoleh dari objek penelitian yang bukan dalam bentuk angka-angka tetapi dalam bentuk lisan maupun tertulis seperti: transparansi, akuntabilitas dan kinerja keuangan pemerintah di Kantor Kecamatan Wanea. Dalam penelitian ini, sumber data yang digunakan adalah: (1) data primer yaitu data yang diperoleh dari Camat dan pegawai-pegawai di Kecamatan Wanea dengan mengajukan daftar pertanyaan mengenai tata kelola yang terdiri dari transparansi dan akuntabilitas serta kinerja keuangan pemerintah; dan (2) data sekunder yaitu data yang diperoleh melalui buku-buku literatur, jurnal-jurnal, catatan atau informasi dari pihak lain yang berkaitan dengan penelitian ini. Metode pengumpulan data yang digunakan yaitu observasi dimana pengumpulan data dilakukan dengan cara mewawancarai secara langsung Camat Kecamatan Wanea dan pegawai-pegawai serta memberikan daftar pertanyaan. Analisis data dalam penelitian ini adalah analisis data kualitatif berdasarkan hasil analisis data kuantitatif yaitu data tentang tata kelola publik dan kinerja keuangan pada Kantor Kecamatan Wanea Kota Manado. 


\section{HASIL PENELITIAN DAN PEMBAHASAN}

\subsection{Hasil penelitian}

Deskripsi atas transparansi pada Kantor Kecamatan Wanea adalah:

a. Pengumum Kebijakan Anggaran Pendapatan dan Belanja Daerah (APBD). Pengumuman kebijakan Anggaran Pendapatan dan Belanja Daerah (APBD) di Kantor Kecamatan Wanea sangat jelas yaitu dengan mengadakan rapat tahunan yang diselenggarakan pada awal tahun dan akhir tahun yang umumnya disebut Musrenbang. Rapat tersebut beranggotakan Camat, Lurah, Kepala-kepala lingkungan, serta tokoh-tokoh masyarakat dalam wilayah Kecamatan Wanea. Rapat tersebut berisikan tentang Anggaran Pendapatan dan Belanja Daerah (APBD) tahun berjalan dan apa yang menjadi progam prioritas pemerintah untuk satu tahun kedepannya.

b. Penyediaan Dokumen Anggaran dan Pendapatan yang mudah diakses. Pemerintah Kecamatan Wanea memberikan informasi yang berhubungan dengan anggaran dan pendapatan secara terbuka, artinya masyarakat secara langsung dapat mengetahui hal-hal yang berhubungan dengan anggaran dan pendapatan dengan cara datang langsung ke Kantor Kecamatan. Pemerintah juga memanfaatkan media aplikasi untuk memberikan informasi melalui situs e-government tentang hal-hal yang berhubungan dengan anggaran dan pendapatan Kecamatan Wanea.

c. Laporan pertanggungjawaban yang tepat waktu. Ketepatan waktu dalam memberikan laporan pertanggungjawaban menggambarkan tingkat responsivitas dari birokrasi dalam menanggapi kebutuhan dan kepentingan masyarakat. Ketepatan waktu ini terlihat dari sejumlah target waktu yang dapat dipenuhi sesuai waktu yang telah ditentukan.

d. Pengakomodasian suara/usulan masyarakat. Semua warga masyarakat mempunyai suara dalam pengambilan keputusan, baik secara langsung maupun melalui lembaga-lembaga perwakilan sah yang mewakili kepentingan mereka. Partisipasi menyeluruh tersebut dibangun berdasarkan kebebasan berkumpul dan mengungkapkan pendapat dan usulan.

e. Pemberian informasi kepada publik. Pemerintah Kecamatan Wanea juga memanfaatkan media sosial untuk memberikan informasi berkaitan kepada masyarakat, seperti WhatsApp dan Facebook.

Deskripsi akuntabilitas pada Kantor Kecamatan Wanea adalah:

a. Kemampuan menyajikan informasi penyelenggaraan pemerintah secara terbuka, cepat, dan tepat kepada masyarakat. Secara umum penyajian informasi di Kantor Kecamatan Wanea merujuk pada tanggungjawab atas pelaksanaan tugas yang diberikan oleh pimpinan. Tanggungjawab yang dimaksud adalah untuk penyelenggaraan pemerintah secara terbuka, cepat, dan tepat kepada masyarakat berdasarkan tugas pokok dan fungsinya masing-masing sesuai visi dan misi Pemerintah Kota Manado.

b. Kemampuan memberikan pelayanan yang memuaskan bagi publik. Kemampuan layanan dilihat dari tingkat kemudahan atas pelayanan yang diberikan kepada masyarakat terutama dari sisi kesederhanaan alur pelayanan serta keahlian, kecakapan, dan keterampilan yang dimiliki para pegawai Kecamatan Wanea dalam memberikan atau menyelesaikan pelayanan kepada masyarakat.

c. Kemampuan memberikan ruang bagi masyarakat. Pemerintah Kecamatan Wanea cukup peka dan cepat tanggap dalam menanggapi aspirasi masyarakat serta menghadapi persoalan-persoalan yang terjadi di masyarakat. Hal tersebut didukung dengan adanya fasilitas layanan pengaduan masyarakat atau pemanfaatan media komunikasi.

d. Kemampuan menjelaskan dan mempertanggungjawabkan setiap kebijakan publik secara proporsional. Prinsip keterbukaan dari Kantor Kecamatan Wanea tidak mengurangi kewajiban untuk menjaga kerahasiaan urusan kepemerintahan sesuai dengan peraturan perundang-undangan, rahasia jabatan, dan hak- hak pribadi. 
e. Penyediaan sarana bagi publik untuk menilai kinerja pemerintah. Kebijakan Kantor Kecamatan Wanea telah dituangkan secara tertulis dan telah disosialisasikan kepada pemangku kepentingan.

Deskripsi kinerja dari penelitian ini didasarkan pada tanggapan pegawai terhadap kinerja keuangan pemerintah di Kecamatan Wanea, dimana konsep transparansi didasarkan pada 5 indikator yaitu pencapaian target kinerja yang telah ditetapkan, pengawasan dan evaluasi kinerja dengan perbandingan skema kerja dan pelaksanaannya, serta ukuran kinerja yang digunakan. Kinerja keuangan merupakan hasil proses kegiatan instansi pemerintah serta dapat digunakan untuk pengambilan keputusan secara objektif. Berikut deskripsi kinerja pada Kantor Kecamatan Wanea dijelaskan secara berturut-turut:

1. Pencapaian target kinerja yang telah ditetapkan. Kantor Kecamatan Wanea telah menyediakan informasi secara tepat waktu, memadai, jelas, akurat, dan dapat diperbandingkan serta mudah diakses oleh pemangku kepentingan sesuai dengan kebutuhannya.

2. Pengawasan dan evaluasi kinerja dengan perbandingan skema kerja dan pelaksanaannya. Semua pegawai yang ada di Kantor Kecamatan Wanea mempunyai kompetensi sesuai dengan tugas, tanggung jawab, dan perannya dalam penerapan good governance dimana Camat selaku Pimpinan selalu melakukan tindakan pengawasan serta penerapan evaluasi kinerja dengan membandingkan skema kerja dan pelaksanaannya sesuai ketentuan dan peraturan yang berlaku.

3. Ukuran yang digunakan dalam menilai kinerja. Kantor Kecamatan Wanea memiliki ukuran kinerja untuk semua jajaran sesuai dengan peraturan perundang-undangan.

4. Kinerja keuangan dan proses kegiatan instansi pemerintah. Kantor Kecamatan Wanea telah memastikan adanya sistem pengendalian internal yang efektif dalam pengelolaan organisasi baik dari segi pemerintahan maupun keuangan sehingga kinerja keuangan pada Kantor Camatan Wanea merupakan hasil capaian atas proses kegiatan instansi pemerintah yang berdasarkan tata kelola pemerintahan yang baik.

5. Pengambilan keputusan secara objektif. Kebijakan Kantor Kecamatan Wanea telah tertulis dan telah disosialisasikan pada pemangku kepentingan sehingga pengambilan keputusan dilakukan oleh Camat secara objektif.

\subsection{Pembahasan}

Transparansi pada Kantor Camat Wanea dibuktikan dengan adanya pengumuman kebijakan Anggaran Pendapatan dan Belanja Daerah (APBD) di Kantor Kecamatan Wanea. Selain itu, Pemerintah Kecamatan Wanea mengadakan rapat tahunan yang diselenggarakan pada awal tahun dan akhir tahun atau Musrenbang. Sesuai Undang-Undang Nomor 32 Tahun 2004 tentang Anggaran Pendapatan dan Belanja Daerah (APBD) maka rencana keuangan tahunan pemerintah daerah dibahas dan disetujui bersama oleh Pemerintah Daerah dan Dewan Perwakilan Rakyat Daerah (DPRD) untuk selanjutnya ditetapkan dengan Peraturan Daerah (Perda). Kecepatan dalam memberikan laporan pertanggungjawaban menggambarkan tingkat responsivitas dari birokrasi dalam menanggapi kebutuhan dan kepentingan masyarakat. Ketepatan terlihat dari sejumlah target waktu yang dapat dipenuhi sesuai waktu yang telah ditentukan. Transparansi Pemerintah Kecamatan Wanea juga dapat dibuktikan dengan adanya kesempatan bagi masyarakat untuk mempengaruhi kebijakan dan alokasi anggaran dengan memberikan saran dari perspektif kreatif didalam rapat yang diadakan.

Semua warga masyarakat mempunyai suara dalam pengambilan keputusan baik secara langsung maupun melalui lembaga-lembaga perwakilan sah yang mewakili kepentingan mereka. Partisipasi menyeluruh tersebut dibangun berdasarkan kebebasan berkumpul dan mengungkapkan pendapat dan usulan. Transparan sebuah kebijakan publik akan semakin meningkat karena masyarakat juga terlibat dalam mengawasi kebijakan publik tersebut. Masyarakat dapat memperoleh informasi secara langsung dari Kantor Kecamatan 
Wanea atau memanfaatkan media sosial yang telah disediakan. Hal ini bertujuan agar masyarakat secara umum dapat melakukan pengawasan atas keputusan dan kinerja pemerintah.

Kinerja keuangan dalam era reformasi sektor publik mengharapkan pemerintah dapat melaporkan hasil dari program yang telah dijalankan untuk dapat dinilai apakah pemerintah bekerja secara ekonomis, efektif, dan efisien. Kinerja keuangan pemerintah menjadi fokus perhatian baik oleh pejabat pemerintah maupun pemangku kepentingan. Kinerja keuangan pemerintah daerah merupakan tingkat pencapaian dari suatu hasil kinerja di bidang keuangan daerah yang meliputi penerimaan dan belanja daerah dengan menggunakan indikator keuangan yang diterapkan melalui suatu kebijakan atau ketentuan perundang-undangan selama satu periode anggaran (Halim, 2016:34).

\section{KESIMPULAN DAN SARAN}

\subsection{Kesimpulan}

Berdasarkan pembahasan penelitian ini, maka dapat disimpulkan bahwa:

1. Pelaksanaan transparansi di Kantor Kecamatan Wanea sudah baik, dimana terdapat pengumuman kebijakan APBD, penyediaan dokumen anggaran dan pendapatan yang mudah diakses, laporan pertanggungjawaban yang tepat waktu, pengakomodasian suara/usulan masyarakat dan pemberian informasi kepada publik.

2. Pelaksanaan akuntabilitas di Kantor Kecamatan Wanea sudah baik karena kemampuan menyajikan informasi penyelenggaraan pemerintah secara terbuka, cepat, tepat, mampu memberikan pelayanan optimal bagi publik, mampu memberikan ruang bagi masyarakat, mampu menjelaskan dan mempertanggungjawabkan setiap kebijakan publik, serta mampu menyediakan sarana bagi publik untuk menilai kinerja pemerintah.

3. Kinerja keuangan di Kantor Kecamatan Wanea sudah baik karena adanya pencapaian target kinerja yang telah ditetapkan, pengawasan dan evaluasi kinerja, ukuran kinerja keuangan sebagai pedoman proses kegiatan instansi pemerintah, serta pengambilan keputusan secara objektif.

\subsection{Saran}

Saran dari penelitian ini adalah:

1. Kantor Kecamatan Wanea disarankan agar terus melakukan pengukuran kinerja aparatur dalam memberikan pelayanan agar terciptanya pemerintahan yang baik.

2. Pemerintahan Kecamatan Wanea agar tetap menerapkan aturan hukum/sanksi tegas bagi aparatur guna mempertahankan roda pemerintahan Kecamatan yang baik.

\section{DAFTAR PUSTAKA}

Halim, A. (2016). Akuntansi sektor publik, akuntansi keuangan daerah. Jakarta: Salemba Empat.

Halim, A., \& Kusufi, S, M (2014). Teori, konsep, dan aplikasi: Akuntansi sektor publik, Edisi Kedua. Jakarta: Salemba Empat.

Hasana, N., \& Fauzi, A. (2017). Akuntansi pemerintahan. Bogor: In Media.

Kuncoro, M. (2014). Metode riset untuk bisnis dan ekonomi bagaimana meneliti dan menulis, Edisi Keempat. Jakarta: Erlangga.

Mardiasmo. (2016). Perpajakan, Edisi Terbaru. Yogyakarta: Andi.

Mursyidi. (2013). Akuntansi pemerintahan di Indonesia. Bandung: PT. Refika Aditama.

Mahmudi. (2018). Akuntansi sektor publik, Edisi Revisi. Yogyakarta: UII Press.

Mulyadi. (2002). Auditing buku 1, Edisi Keenam. Jakarta: Salemba Empat.

Munawir. (2016). Akuntansi sektor publik, Edisi Keempat. Yogyakarta: BPFE. 
Nordiawan, D., Putra, I, S., \& Rahmawati, M. (2009). Akuntansi pemerintahan. Jakarta: Salemba Empat.

Sujarweni, V. W. (2015). Akuntansi sektor publik. Yogyakarta: Pustaka Baru Press.

Undang-Undang Nomor 17 Tahun 2003 tentang Keuangan Negara.

Undang-Undang Nomor 1 Tahun 2004 tentang Perbendaharaan Negara.

Undang-Undang Nomor 15 Tahun 2004 tentang Pemeriksaan Pengelolaan dan Tanggung Jawab Keuangan Negara.

Undang-Undang Nomor 32 Tahun 2004 tentang Pemerintah Daerah.

Undang-Undang Nomor 33 Tahun 2004 tentang Perimbangan Keuangan antara Pusat dan Pemerintah Daerah.

Walangitan, F. O. (2014). Analisis kinerja pemerintah kecamatan dalam pelayanan publik di Kecamatan Bone Kabupaten Bone Bolango Propinsi Gorontalo. Jurnal Administrasi Publik, 2(002), 1-13. https://ejournal.unsrat.ac.id/index.php/JAP/article/view/4730. 